\begin{tabular}{lccccccccccccc}
\hline Case & Age & HIV, Y & TN, Y & Sx & VAS & BMI & alkphos & PO4 & Cr & K+ & NTX & FemN & LS \\
\hline 1 & 49 & 10 & 4 & 8 & 80 & 20.4 & 309 & 2.2 & 1.80 & 2.9 & 128 & -3.5 & -4.2 \\
2 & 69 & 32 & 10 & 8 & 70 & 18.0 & 245 & 1.5 & 1.33 & 4.2 & 57 & -2.6 & -2.3 \\
3 & 61 & 30 & 7 & 36 & 84 & 20.0 & 576 & 1.2 & 1.18 & 3.3 & 98 & -3.2 & -3.8
\end{tabular}

$\mathrm{Y}=$ years, $\mathrm{Sx}=$ symptoms in months, VAS = visual analogue scale, alkphos = alkaline phosphatase $(39-117 \mathrm{IU} / \mathrm{L}), \mathrm{PO} 4=$ phosphorus $(2.5-4.5 \mathrm{mg} / \mathrm{dL}), \mathrm{Cr}=$ creatinine $(0.76-1.27 \mathrm{mg} / \mathrm{dL})$, $\mathrm{K}_{+}=$potassium $(3.5-5.2 \mathrm{mml} / \mathrm{L})$, FemN $=$ femoral neck $\mathrm{T}$-score, $\mathrm{LS}=$ lumbar spine T-score.

sacrum in all three patients. A MRI of the knee showed bone marrow edema in case 2 and an atypical longitudinal fracture of the femur in case 3 . Tenofovir was withdrawn, oral phosphates given, and resolution of pain and biochemical changes occurred in 4-8 months. Bone mineral density in case 1 repeated 1 year after presentation increased $16 \%$ in the femoral neck and $19 \%$ in the lumbar spine.

The laboratory and clinical features in our cases shared with those previously reported include long duration of HIV and tenofovir treamtent, severe pain and disability, low BMI, neuropathy, hypogonadism in men, elevation of alkaline phoshatase and varying degrees of renal tubular dysfunction.

Conclusions: Long term tenofovir therapy in HIV patients can induce a devastating disabling osteomalacia caused by hypophosphatemia with features of Fanconi syndrome with or without vitamin D deficiency. A long standing history of HIV infection, low BMI, neuropathy, and hypogonadism in male patients may predispose or be associated with this complication. A serum phosphorus, alkaline phosphatase, and urinalysis should be followed regularly in all tenofovir treated patients to avoid the consequences of osteomalacia.

References:

[1] Karras A, et al, Clin Infect Dis 2003; 36:1070-1072.

[2] Earle KE, et al, J Bone Miner Dis 2004; 19:714-721.

[3] Mateo L, et al, Clin Rheumatol 2016; 35:1271-1279.

Disclosure of Interest: None declared

DOI: 10.1136/annrheumdis-2017-eular.2644

\section{AB0889 FACTORS CONTRIBUTING TO LENGTH OF INPATIENT HOSPITAL STAY FOR PATIENTS WITH ACUTE GOUT ARTHROPATHY AT THE NORTHERN HOSPITAL: AN OBSERVATIONAL STUDY}

M. Mian $^{1,2}$, M.N. Hossain ${ }^{3}$, M. Omair ${ }^{1}$, D. Liew ${ }^{1,2}$, C.E. Owen ${ }^{1,4}$, A.M. Foote $^{1,2}$ R.R.C. Buchanan 1,2,4 . ${ }^{1}$ Department of Medicine, Austin Health; ${ }^{2}$ Department of Medicine, Northern Health; ${ }^{3}$ School of Public Health and Preventive Medicine, Monash University; ${ }^{4}$ Department of Medicine, University of Melbourne, Melbourne, Australia

Background: Gout is a common inflammatory arthropathy with a reported prevalence ranging from $1.7 \%$ to $4 \%$ within Australia - one of the highest in the world, second only to New Zealand. ${ }^{1}$ Epidemiological studies have established that its prevalence has increased steadily over recent years, with the impact of the disease on the rise. ${ }^{2}$

Gout has painful and debilitating effects on patients leading to impact on their quality of life. Even though usually managed in the primary care setting, many patients are ultimately admitted as inpatients to hospital with the associated increased resource utilisation and cost. There is a growing recognition of the economic burden of gout. ${ }^{3}$ A Canadian study estimated 5-year total health costs of patients with gout at $\$ 10,332$ more than comparable gout free patients. ${ }^{4}$ Objectives: To identify factors potentially contributing to increased length of inpatient hospital stay for acute exacerbations of gout in a teaching hospital in Melbourne, Australia.

Methods: Patients admitted to The Northern Hospital, Melbourne, Australia with a discharge diagnosis of gout as their only acute medical problem between 1st July 2014 and 30th June 2016 were identified using ICD-10 disease coding from institutional compensation reports. Retrospective chart review was performed identifying length of stay and for variables which may potentially affect it.

Results: 121 patients were discharged with an acute gout flare over the 2 years with a mean age of $66 \pm 15$ years. The vast majority of patients in this cohort were male (86\%). The mean length of stay was 2.3 days (95\% Cl 1.83-2.78 days), with a median of 1 day. The median length of hospital stay was increased by 2 days if patients lived alone $(p=0.042)$ and 1 extra day if the $\mathrm{C}$-Reactive Protein (CRP) measured at admission was $>100 \mathrm{mg} / \mathrm{L}(p=0.001)$. Hospital stay was similarly prolonged by a single day if more than one joint was involved in the flare $(p=0.003)$.

Conclusions: Gout without antecedent acute medical comorbidity is a common acute medical presentation to hospital with a large corresponding economic burden. Factors affecting length of inpatient stay include social status, marked elevation of CRP and polyarticular involvement. This study identifies factors which warrant further investigation as to how they may be ameliorated in order to improve health resource utilisation.

\section{References:}

[1] Smit E, Hoy D, Cross $M$ et al. Burden of disability due to musculoskeletal (MSK) disorders. Ann Rheum Dis 2014; 73: 1470-1476.

[2] Becker MA. Recent developments in the management of gout. Rheumatology 2012;51:i1.

[3] Shields GE, Beard SM. A systematic review of the economic and humanistic burden of gout. PharmacoEconomics 2015;33: 1029-1047.
[4] Fischer A, Cloutier M, Goodfield J, Borrelli R, Marvin D, Dziarmaga A. The direct economic burden of gout in an elderly Canadian population. J Rheumatol 2017;44(1):95-101.

Disclosure of Interest: None declared

DOI: 10.1136/annrheumdis-2017-eular.5632

\section{AB0890 SYSTEMIC LUPUS ERYTHEMATOSUS AND GOUT: REALLY AN UNUSUAL ASSOCIATION?}

$\underline{\text { N. Quilis }}{ }^{1}$, M. Andrés ${ }^{2,3} .{ }^{1}$ Seccion de Reumatologia, Hospital Universitario Vinalopó, Elche; ${ }^{2}$ Seccion de Reumatologia, Hospital General Universitario de Alicante; ${ }^{3}$ Departamento de Medicina Clínica, Universidad Miguel Hernández, Alicante, Spain

Background: Patients with systemic lupus erythematosus (SLE) often suffer from cardiovascular comorbidity such as hypertension, dyslipidemia or coronary heart disease. However, the association with gout - an independent cardiovascular risk factor - is considered unusual - it is not reported in the EULAR textbook (1)-, and might not be taken into account when acute arthritis occurs in SLE patients, also due to the predominance of women in this disease.

Objectives: To review our experience regarding SLE patients who developed gout, and to perform a literature review of reported cases to date.

Methods: Retrospective review of patients with SLE and crystal-proven gout in our Rheumatology Unit, a tertiary care center. We recorded clinical and laboratory variables related to both diseases. Then, we performed a bibliographical review in Pubmed (1965 - 2016) to identify reported cases of coexistence of both diseases. Results: Out 189 SLE patients seen in our Unit, we have identified two cases with crystal-proven gout: 1) A 68 years-old woman with SLE and nephritis diagnosed 30 years ago, who developed polyarthritis affecting her hands. 2) A 47 years-old man with lupus for 22 years with nephritis and renal failure, who developed acute arthritis involving right knee and ankle. In both cases, urate crystals were demonstrated at synovial fluid. The table shows the results of the literature review together with our two cases. To date, 36 cases with coexistent SLE and gout have been reported. Median age at time of gout diagnosis was 43.5 years (p25-75 32.5-52.0), being 26 females (72\%). SUA levels were found notably high (median $13.5 \mathrm{mg} / \mathrm{dL}$ ), and tophi, a marker of gout severity, were demonstrated in almost half of cases $(44.4 \%)$. The majority of patients $(91 \%)$ were on glucocorticoids at time of gout diagnosis. According to common factors leading to hyperuricemia, lupus-related renal damage ( $86 \%$ ) and use of diuretics $(83 \%)$ predominated in the series.

\begin{tabular}{|c|c|c|c|c|c|c|c|c|c|}
\hline Ref. & $\begin{array}{c}\text { Sex \& } \\
\text { Age } \\
\text { (years) }\end{array}$ & $\begin{array}{c}\text { Lupus } \\
\text { Nephritis }\end{array}$ & Diuretics & Corticoids & $\begin{array}{l}\text { Time between } \\
\text { SLE and gout } \\
\text { diagnoses (years) }\end{array}$ & $\begin{array}{c}\text { Acute } \\
\text { arthritis }\end{array}$ & Tophi & $\begin{array}{l}\text { SUA at } \\
\text { diagnosis } \\
\text { (mg/dt) }\end{array}$ & $\begin{array}{l}\text { Other crystals } \\
\text { in synovial fluid }\end{array}$ \\
\hline \multirow{2}{*}{ Quilis 2017} & $F 65$ & Yes & No & No & 30 & Yes & No & 11.1 & No \\
\hline & M 47 & Yes & No & No & 22 & Yes & No & 12.2 & No \\
\hline \multirow{3}{*}{$\begin{array}{c}\begin{array}{c}\text { Moidel } \\
1981\end{array} \\
\text { Wall } 1982\end{array}$} & M 48 & Yes & Yes & Yes & 11 & Yes & No & 10.8 & No \\
\hline & F 39 & Yes & Yes & $?$ & 10 & $?$ & Yes & 12 & No \\
\hline & M 45 & Yes & Yes & Yes & 10 & Yes & No & 8.8 & No \\
\hline Rose 1982 & F 34 & No & No & Yes & 1,5 & Yes & No & ? & $\begin{array}{l}\text { CPP, } \\
\text { hydroxyapatite }\end{array}$ \\
\hline $\begin{array}{c}\text { Helliwell } \\
1982\end{array}$ & M 39 & Yes & $?$ & Yes & 12 & Yes & Yes & 14.8 & No \\
\hline Lally 1982 & F 29 & Yes & Yes & Yes & 9 & Yes & No & 10.2 & No \\
\hline \multirow{2}{*}{$\begin{array}{c}\text { Bradley } \\
1983\end{array}$} & F31 & Yes & Yes & Yes & 4 & Yes & Yes & 16.5 & No \\
\hline & F57 & Yes & $?$ & Yes & 20 & Yes & Yes & 9.5 & No \\
\hline $\begin{array}{c}\text { Rodriguez } \\
1984\end{array}$ & F 17 & Yes & Yes & Yes & 5 & No & Yes & 12 & $\begin{array}{l}\text { CPP, } \\
\text { hydroxyapatite, } \\
\text { cholesterol }\end{array}$ \\
\hline \multirow{2}{*}{$\begin{array}{c}\text { Greenfield } \\
1985\end{array}$} & F56 & Yes & Yes & Yes & 12 & Yes & No & 13.18 & No \\
\hline & M41 & Yes & Yes & Yes & 14 & Yes & No & 9 & No \\
\hline $\begin{array}{c}\text { Tsuboi } \\
1986\end{array}$ & F 25 & Yes & Yes & Yes & 7 & No & Yes & 12.2 & No \\
\hline $\begin{array}{c}\text { Frocht } \\
1987 \\
\end{array}$ & F 37 & Yes & Yes & Yes & 7 & Yes & No & 12.9 & No \\
\hline $\begin{array}{c}\text { McDonold } \\
1988\end{array}$ & M 43 & Yes & Yes & Yes & 10 & No & Yes & 8.3-10.8 & No \\
\hline $\begin{array}{c}\text { Kalmar } \\
1982 \\
\end{array}$ & F 47 & Yes & Yes & Yes & 6 & No & Yes & 16.1 & No \\
\hline $\begin{array}{c}\text { Alarcon } \\
1983 \\
\end{array}$ & F52 & No & ? & ? & 14 & Yes & No & 18 & No \\
\hline Kurita 1989 & F 37 & Yes & Yes & Yes & 15 & No & Yes & 11.4 & No \\
\hline \multirow{3}{*}{$\begin{array}{l}\text { Veerapen } \\
1993\end{array}$} & F 31 & Yes & $?$ & Yes & 11 & Yes & Yes & 11.5 & No \\
\hline & M 24 & Yes & Yes & Yes & 6 & Yes & Yes & 15 & No \\
\hline & M22 & Yes & Yes & Yes & 4 & Yes & Yes & 10.1 & No \\
\hline $\begin{array}{c}\text { McMillen } \\
1994\end{array}$ & F52 & Yes & $?$ & Yes & 7 & Yes & No & 6.9 & No \\
\hline \multirow[t]{7}{*}{ Ho 2003} & F 61 & No & Yes & Yes & 6 & Yes & Yes & 17.3 & No \\
\hline & F 37 & Yes & Yes & Yes & 5 & Yes & Yes & 17.5 & No \\
\hline & $F 30$ & No & Yes & Yes & 8 & Yes & No & 12.9 & No \\
\hline & Fso & Yes & Yes & Yes & 13 & Yes & Yes & 10.3 & No \\
\hline & F 68 & Yes & Yes & Yes & 4 & Yes & No & 9.9 & No \\
\hline & $F 77$ & No & Yes & Yes & 14 & Yes & Yes & 9.2 & No \\
\hline & F33 & Yes & Yes & Yes & 7 & Yes & No & 11.2 & No \\
\hline \multirow[t]{6}{*}{ Bojoj 2004} & $F 22$ & Yes & No & Yes & 9 & $?$ & $?$ & 18.4 & No \\
\hline & $F 44$ & Yes & Yes & Yes & 10 & ? & $?$ & 15.1 & No \\
\hline & M 46 & Yes & Yes & Yes & 9 & $?$ & $?$ & 15.1 & No \\
\hline & M 47 & Yes & No & Yes & 31 & $?$ & $?$ & 13.4 & No \\
\hline & F53 & Yes & Yes & No & 4 & $?$ & $?$ & 15.1 & No \\
\hline & F55 & Yes & Yes & Yes & 21 & ? & $?$ & 6.7 & No \\
\hline
\end{tabular}

Conclusions: Data supports including gout into the differential diagnosis of episodes of acute arthritis in SLE patients. This makes crucial the routine analysis of all synovial fluid samples, but especially in patients with long-term disease, renal impairment, and diuretic use.

References:

[1] EULAR Textbook on Rheumatic Diseases. BMJ, 2015.

Disclosure of Interest: None declared

DOI: 10.1136/annrheumdis-2017-eular.5292 